\title{
An Efficient Synthesis of 2,3-Diaminoacid Derivatives Using Phosphine Catalyst
}

\author{
Yohei Oe', Hiroaki Kishimoto², Nahoko Sugioka², Daisuke Harada², Yukio Sato², \\ Tetsuo Ohta ${ }^{1}$, Isao Furukawa ${ }^{2}$ \\ ${ }^{1}$ Department of Biomedical Information, Faculty of Life and Medical Sciences, Doshisha University, \\ Kyoto, Japan \\ ${ }^{2}$ Department of Molecular Science and Technology, Faculty of Engineering, Doshisha University, \\ Kyoto, Japan \\ Email: yoe@mail.doshisha.ac.jp, tota@mail.doshisha.ac.jp
}

Received 29 June 2014; revised 17 August 2014; accepted 30 August 2014

Copyright (C) 2014 by authors and Scientific Research Publishing Inc.

This work is licensed under the Creative Commons Attribution International License (CC BY).

http://creativecommons.org/licenses/by/4.0/

(c) (i) Open Access

\begin{abstract}
Ethyl 2,3-diphthalimidoylpropanoate was effectively synthesized from ethyl propynoate with two equivalents of phthalimide catalyzed by triphenylphosphine in good yield. The choice of reaction media was important for selective synthesis of the desired 2,3-diaminocarboxylic acid derivatives. The reaction is considered to occur through a zwitterionic intermediate derived from the reaction of the $\alpha, \beta$-unsaturated ester with triphenylphosphine.
\end{abstract}

\section{Keywords}

\section{Addition, Alkynes, Amino Acids, Catalysis, Multi-Component Reaction}

\section{Introduction}

2,3-Diaminoacids and their derivatives have attracted a great deal of attention due to their application as key structural fragments of biologically active compounds [1]-[7], and/or as ligands for metal complexes [8]-[13]. Various methods to prepare these compounds have been reported [1] [2] [4] [14]-[19].

While studying the $\mathrm{PPh}_{3}$-catalyzed three-component coupling of ethyl propynoate, a nitrogen nucleophile, and an aldehyde [20], we found an efficient synthesis of 2,3-diaminoacid derivatives from ethyl propynoate and phthalimide catalyzed by triphenylphosphine. Further details on this synthesis are described in this report.

\section{Results and Discussion}

Reaction of ethyl propynoate (1) with phthalimide (2) in the presence of a stoichiometric amount of triphenyl-

How to cite this paper: Oe, Y., Kishimoto, H., Sugioka, N., Harada, D., Sato, Y., Ohta, T. and Furukawa, I. (2014) An Efficient Synthesis of 2,3-Diaminoacid Derivatives Using Phosphine Catalyst. International Journal of Organic Chemistry, 4, 189-194. http://dx.doi.org/10.4236/ijoc.2014.43021 
phosphine at room temperature gave ethyl 2,3-diphthalimidoylpropanoate (3) together with ethyl 2-phthalimidoylpropenoate (4) (Scheme 1). The ratio of $\mathbf{3}$ and $\mathbf{4}$ depended on the solvent used (Table 1). $\mathbf{3}$ was produced when highly polar solvents, such as DMSO, DMF, acetonitrile, and ketone were used. In these cases, $\mathbf{3}$ was obtained at more than $70 \%$ with no formation of $\mathbf{4}$. When 2-pyrrolidone was used, a mixture of $\mathbf{3}$ and $\mathbf{4}$ was obtained in 44 and 19\% yields, respectively. However, the dehydroamino acid derivative $\mathbf{4}$ was mainly produced when a less polar solvent was used [21]. In esters, ethers, halogenated hydrocarbons, and aromatic solvents, 4 was obtained in moderate to good yields with no formation of $\mathbf{3}$.

DMSO and 2-butanone were selected to examine the effect of reaction temperature on the reaction (Table 2). The reaction in DMSO at room temperature for a short reaction time gave mostly 4 . However, when the reaction time was increased, the yield of $\mathbf{4}$ began to decrease, while the yield of product $\mathbf{3}$ began to increase. Compound 3 was obtained in $97 \%$ yield at $100^{\circ} \mathrm{C}$ and $87 \%$ yield at room temperature (Table 2, entry 8 and 11). In the 2-butanone solvent, it was also found that higher temperatures gave a better yield of $\mathbf{3}$.

The concentration of the substrates did not affect the yield of $\mathbf{3}$; the reaction of $1 \mathrm{mmol}$ of substrate $\mathbf{1}, 2 \mathrm{mmol}$ of phthalimide (2), and $1 \mathrm{mmol}$ of $\mathrm{PPh}_{3}$ in 1, 2, or $5 \mathrm{~mL}$ of DMSO gave 3 in $81 \%, 87 \%$, and $88 \%$ yields, respectively, which were not significantly different.

This reaction also proceeded under other phosphines (Table 3). For example, the reaction progressed efficiently, when triphenylphosphine, tri(p-fluorophenyl)phosphine, and tri( $p$-methoxyphenyl)phosphine were used. These phosphines were found to act as catalysts [22]. For example, the reaction at room temperature for $24 \mathrm{~h}$ using $10 \mathrm{~mol} \%$ triphenylphosphine resulted in $82 \%$ yield of 3 . In contrast, the yield significantly decreased when tributylphosphine was used. Moreover, no reaction occurred when pyridine was used [23].

Other nucleophiles were also investigated. Trost et al. reported that $\mathbf{4}$ was formed in $95 \%$ yield from the reaction catalyzed by triphenylphosphine in a mixture of toluene and a buffer solution of acetic acid and sodium acetate at $105^{\circ} \mathrm{C}$ [24]. They found that using $p$-toluenesulfoamide as a substrate gave a trace amount of $\mathbf{3}$. Di-

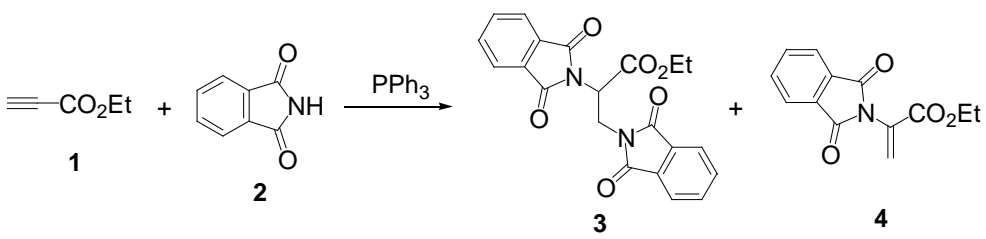

Scheme 1. Reaction of ethyl propynoate with phthalimide catalyzed by $\mathrm{PPh}_{3}$.

Table 1. Effect of solvent ${ }^{\mathrm{a}}$.

\begin{tabular}{|c|c|c|c|c|c|}
\hline \multirow{2}{*}{ Entry } & \multirow{2}{*}{ Solvent } & \multirow{2}{*}{$\mu(D)^{6}$} & \multirow{2}{*}{$\varepsilon_{\rho} /{ }^{\circ} \mathrm{C}$} & \multicolumn{2}{|c|}{ Yield $(\%)$} \\
\hline & & & & 3 & 4 \\
\hline 1 & DMSO & 4.30 & $48.9 / 20$ & 87 & - \\
\hline 2 & DMF & 3.86 & $36.71 / 20$ & 81 & - \\
\hline 3 & $\mathrm{CH}_{3} \mathrm{CN}$ & 3.44 & $37.5 / 20$ & 73 & - \\
\hline 4 & 2-Butanone & - & - & 84 & - \\
\hline 5 & Acetone & 2.69 & $20.70 / 25$ & 82 & - \\
\hline 6 & 2-Pyrrolidone & 2.30 & - & 44 & 19 \\
\hline 7 & Ethyl Benzoate & 1.99 & $5.98 / 25$ & - & 72 \\
\hline 8 & Ethyl Acetate & 1.88 & $6.02 / 20$ & - & 81 \\
\hline 9 & THF & 1.70 & $7.58 / 25$ & - & 82 \\
\hline 10 & $\mathrm{CHCl}_{3}$ & 1.15 & $4.90 / 20$ & - & 60 \\
\hline 11 & $\mathrm{CH}_{2} \mathrm{Cl}_{2}$ & 1.14 & $9.10 / 20$ & - & 72 \\
\hline 12 & Diethyl Ether & 1.12 & $4.20 / 27$ & - & 55 \\
\hline 13 & 1,4-Dioxane & 0.45 & $2.70 / 25$ & - & 94 \\
\hline 14 & Toluene & 0.40 & $2.24 / 20$ & - & 52 \\
\hline 15 & Benzene & 0 & $2.28 / 20$ & - & 58 \\
\hline
\end{tabular}

${ }^{\mathrm{a}} \mathrm{A}$ mixture of ethyl propynoate $(1.0 \mathrm{mmol})$, phthalimide $(2.0 \mathrm{mmol}), \mathrm{PPh}_{3}(1.0 \mathrm{mmol})$ was stirred in a solvent $(2.0 \mathrm{~mL})$ at room temperature for $24 \mathrm{~h}$. ${ }^{\mathrm{b}}$ Yields were determined by ${ }^{1} \mathrm{H}$ NMR using internal standard (bibenzyl) method. 
Table 2. Effect of reaction time and temperature ${ }^{\mathrm{a}}$.

\begin{tabular}{cccccc}
\hline Entry & Solvent & Time $(\mathrm{h})$ & Temp. $\left({ }^{\circ} \mathrm{C}\right)$ & \multicolumn{3}{c}{ Yield $(\%)$} \\
\cline { 4 - 5 } & & & & 3 & 4 \\
2 & DMSO & $5(\mathrm{~min})$ & r.t. & 4 & 21 \\
3 & DMSO & $10(\mathrm{~min})$ & r.t. & 36 & 32 \\
4 & DMSO & 0.5 & r.t. & 66 & 76 \\
5 & DMSO & 1 & r.t. & 84 & 7 \\
6 & DMSO & 1.5 & r.t. & 86 & 4 \\
7 & DMSO & 3 & r.t. & 86 & - \\
8 & DMSO & 6 & r.t. & 87 & - \\
9 & DMSO & 24 & r.t. & 84 & - \\
10 & DMSO & 48 & 100 & 94 & - \\
11 & DMSO & 6 & 100 & 97 & - \\
12 & DMSO & 24 & 100 & 97 & - \\
13 & DMSO & 48 & r.t. & 84 & - \\
14 & 2 -Butanone & 24 & 80 & 89 & - \\
\hline
\end{tabular}

${ }^{a}$ A mixture of ethyl propynoate $(1.0 \mathrm{mmol})$, phthalimide $(2.0 \mathrm{mmol}), \mathrm{PPh}_{3}(1.0 \mathrm{mmol})$ was stirred in a solvent $(2.0 \mathrm{~mL})$ at room temperature. ${ }^{\mathrm{b}}$ Yields were determined by ${ }^{1} \mathrm{H}$ NMR using internal standard (bibenzyl) method.

Table 3. Effect of phosphine ${ }^{\mathrm{a}}$.

\begin{tabular}{cccc}
\hline Entry & Phosphine/1 (mol\%) & \multicolumn{3}{c}{ Yield $(\%)^{\mathrm{b}}$. } & 4 \\
\cline { 2 - 3 } & & 3 & - \\
2 & $\mathrm{PPh}_{3}(10)$ & 82 & - \\
3 & $\mathrm{PPh}_{3}(30)$ & 87 & - \\
4 & $\mathrm{PPh}_{3}(50)$ & 86 & - \\
5 & $\mathrm{PPh}_{3}(100)$ & 87 & - \\
6 & $\mathrm{P}\left(p-\mathrm{C}_{6} \mathrm{H}_{4} \mathrm{~F}\right)_{3}(30)$ & 78 & - \\
7 & $\mathrm{P}\left(p-\mathrm{C}_{6} \mathrm{H}_{4} \mathrm{OMe}\right)_{3}(30)$ & 88 & - \\
8 & $\mathrm{PMePh}_{2}(30)$ & 67 & 14 \\
\hline
\end{tabular}

${ }^{\mathrm{a}}$ A mixture of ethyl propynoate $(1.0 \mathrm{mmol})$, phthalimide $(2.0 \mathrm{mmol})$, phosphine $(0.1-1.0 \mathrm{mmol})$ was stirred in dimethylsulfoxide (2.0 mL) at room temperature for $24 \mathrm{~h}$. ${ }^{\text {}}$ Yields were determined by ${ }^{1} \mathrm{H}$ NMR using internal standard (bibenzyl) method.

acetamide, maleimide, benzylamine, allylamine, $N$-methyl-p-toluenesulfoamide, dimethyl malonate, and acetylacetone were also investigated, and they were found to give a 1:1 ratio of 3 and $\mathbf{4}$. Methyl- and phenyl- substituted propynoates were not converted to the desired 2,3-diaminoacid derivatives.

The reaction of $\mathbf{4}$ with phthalimide was also examined (Table 4). Without the presence of $\mathrm{PPh}_{3}, \mathbf{3}$ was not produced On the other hand, in the presence of $\mathrm{PPh}_{3}, \mathbf{3}$ was formed in good yield after $24 \mathrm{~h}$. However, this reaction did not proceed in $\mathrm{CH}_{2} \mathrm{Cl}_{2}$.

The proposed reaction mechanism is shown in Scheme 2. First, triphenylphosphine attacks the propynoate to give zwitterionic intermediate 5 [25]-[39]. The intermediate subsequently remove a proton from phthalimide, giving a vinylphosphonium salt with a phthalimidate anion. The anion adds to the salt via Michael addition, followed by a proton transfer and elimination of phosphine to give 4 . $\mathrm{PPh}_{3}$ attacks 4 again to give zwitterionic intermediate $\mathbf{7}$, which acts as a base to form another phthalimidate anion. This anion then attacks $\mathbf{4}$ by nucleophilic substitution to afford $\mathbf{3}$. Solvent effect is considered to stabilize zwitterionic intermediates $\mathbf{5}$ and $\mathbf{7}$.

\section{Conclusion}

$\alpha, \beta$-Diamino acid derivatives are efficiently prepared by the reaction of propynoate with phthalimide in the 
Table 4. Synthesis 3 from the reaction of 4 and phthlimide ${ }^{a}$.

\begin{tabular}{ccccc}
\hline Entry & Solvent & $\mathrm{PPh}_{3}$ & \multicolumn{3}{c}{ Ratio $^{\mathrm{b}}(\%)$} \\
\cline { 3 - 5 } & & & 3 & 25 \\
2 & DMSO & Yes & 75 & 100 \\
3 & $\mathrm{DMSO}$ & No & - & 21 \\
4 & $\mathrm{CH}_{3} \mathrm{CN}$ & Yes & - & 100 \\
\hline
\end{tabular}

${ }^{\mathrm{a}} \mathrm{A}$ mixture of $4(1.0 \mathrm{mmol})$, phthalimide $(1.0 \mathrm{mmol}), \mathrm{PPh}_{3}(30 \mathrm{~mol} \%$ or 0$)$ was stirred in a solvent at room temperature for $24 \mathrm{~h} .{ }^{\mathrm{b}}$ Yields were determined by ${ }^{1} \mathrm{H}$ NMR using internal standard (bibenzyl) method.
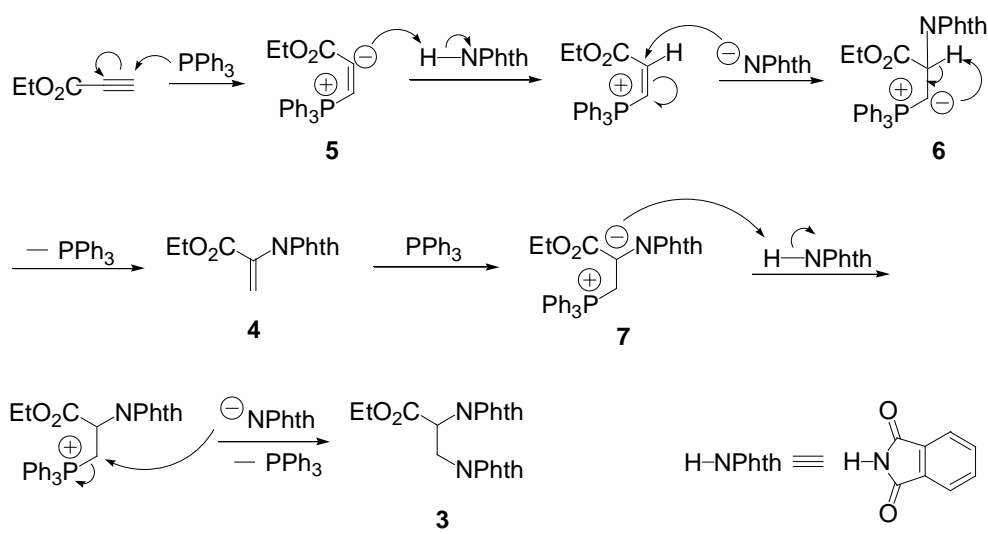

Scheme 2. Proposed mechanism.

presence of catalytic amount of triphenylphosphine. This method is very simple and the yield of the product is almost quantitative. Furthermore, if optically active amino acids could be prepared, this method might become more usable. Our first trial of the reaction using chiral phosphines gave racemic product. But now preliminary results using chiral additives indicate the possibility to yield the optically active product. Now establishment of asymmetric reaction is underway.

\section{Experimental}

\subsection{General}

Proton nuclear magnetic resonance $\left({ }^{1} \mathrm{H}\right.$ NMR) spectra were measured using a JEOL JNM A-400 (400 MHz) spectrometer using tetramethylsilane as the internal standard. IR spectra were measured on a Shimadzu IR-408 spectrometer. Mass spectral (GC-MS) data were recorded on a Shimadzu QP2000A instrument. Melting points were measured on a Yanako Model MP and were not corrected. All substrates were purchased and used without further purification except triphenylphosphine and phthalimide (recrystalization from methanol). Solvents were purified according to the literature method and stored under Ar atmosphere [40].

\subsection{Typical Experimental Procedure}

Into a dry $80 \mathrm{~mL}$ Schlenk tube were added phthalimide $(2.0 \mathrm{mmol})$, triphenylphosphine (0.3 mmol), and DMSO (2 mL). To this mixture, ethyl propynoate $(1.0 \mathrm{mmol})$ was added dropwise, and the mixture was stirred for $24 \mathrm{~h}$. The yield was determined by internal standard (bibenzyl) method. That is, bibenzyl (0.25 mmol) was added to the reaction mixture, and then concentrated mixture was analyzed by ${ }^{1} \mathrm{H}$ NMR. The integration area of $5.17 \mathrm{ppm}$ (product 3), 5.97 ppm (byproduct 4), and 2.91 ppm (bibenzyl) was used to determining the yields of 3 and/or 4. Reaction mixture was purified by column chromatography (silica gel 60, 200 - 400 mesh, hexane-ethyl acetate) to give the product.

\subsection{Identification of the Products}

Ethyl 2,3-diphthalimidoylpropanoate (3): Yellow solid, ${ }^{1} \mathrm{H}$ NMR $\left(\mathrm{CDCl}_{3}\right) \delta 7.82-7.81$ (m, $\left.4 \mathrm{H}\right), 7.77-7.67$ 
(m, 4H), 5.17 (dd, $J=9.2,5.6 \mathrm{~Hz}, 1 \mathrm{H}), 4.53-4.45$ (m, 2H), 4.28 (q, $J=7.2 \mathrm{~Hz}, 2 \mathrm{H}), 1.27$ (t, $J=7.2 \mathrm{~Hz}, 3 \mathrm{H})$;

${ }^{13} \mathrm{C}$ NMR $\left(\mathrm{CDCl}_{3}\right) \delta 167.8,167.2,166.8,134.2,134.1,131.5,62.3,50.4,36.8,14.0$; IR (KBr) 2960, 1760, 1724, $1600,1380,1220,1085,1030,720, \mathrm{~cm}^{-1}$; GC-MS(m/z) 392; mp. $132^{\circ} \mathrm{C}-133^{\circ} \mathrm{C}$.

Ethyl 2-phthalimidoylpropenoate (4): White solid, ${ }^{1} \mathrm{H}$ NMR $\left(\mathrm{CDCl}_{3}\right) \delta 7.91$ - $7.87(\mathrm{~m}, 2 \mathrm{H}), 7.79$ - 7.75 (m, 2H), $6.66(\mathrm{~s}, 1 \mathrm{H}), 5.97(\mathrm{~s}, 1 \mathrm{H}), 4.26(\mathrm{q}, J=7.14 \mathrm{~Hz}, 2 \mathrm{H}), 1.28(\mathrm{t}, J=7.12 \mathrm{~Hz}, 3 \mathrm{H}) ;{ }^{13} \mathrm{C}$ NMR $\left(\mathrm{CDCl}_{3}\right) \delta 166.5$, 162.3, 134.5, 131.8, 129.4, 127.8, 123.9, 61.9, 13.9; IR (KBr) 3150, 2960, 1790, 1724, 1639, 1400, 1380, 1250, 1070, 1030, $720, \mathrm{~cm}^{-1}$; GC-MS(m/z) $245 ; \mathrm{mp} .71^{\circ} \mathrm{C}-72^{\circ} \mathrm{C}$.

\section{References}

[1] Viso, A., de la Pradilla, R.F., García, A. and Flores, A. (2005) $\alpha, \beta$-Diamino Acids: Biological Significance and Synthetic Approaches. Chemical Reviews, 105, 3167-3196. http://dx.doi.org/10.1021/cr0406561

[2] Viso, A., de la Pradilla, R.F., Tortosa, M., García, A. and Flores, A. (2011) Update 1 of: $\alpha, \beta$-Diamino Acids: Biological Significance and Synthetic Approaches. Chemical Reviews, 111, PR1-PR42. http://dx.doi.org/10.1021/cr100127y

[3] Qian, H., Fu, Z., Huang, W., Zhang, H., Zhou, J., Ge, L., Lin, R., Lin, H. and Hu, X. (2010) Synthesis and Preliminary Biological Evaluation of Capsaicin Derivatives as Potential Analgesic Drugs. Journal of Medicinal Chemistry, 6, 205210.

[4] Moura, S. and Pinto, E. (2010) Synthesis of Cyclic Guanidine Intermediates of Anatoxin-a(s) in Both Racemic and Enantiomerically Pure Forms. SYNLETT, 967-969. http://dx.doi.org/10.1055/s-0029-1219559

[5] Ellsworth, B.A., Wang, Y., Zhu, Y., Pendri, A., Gerritz, S.W., Sun, C., Carlson, K.E., Kang, L., Baska, R.A., Yang, Y., Huang, Q., Burford, N.I., Cullen, M.J., Johnghar, S., Behnia, K., Pelleymounter, M.A., Washburn, W.N. and Ewing, W.R. (2007) Discovery of Pyrazine Carboxamide CB1 Antagonists: The Introduction of a Hydroxyl Group Improves the Pharmaceutical Properties and in Vivo Efficacy of the Series. Bioorganic Medicinal Chemistry Letters, 17, 39783982. http://dx.doi.org/10.1016/j.bmcl.2007.04.087

[6] Boström, J., Berggren, K., Elebring, T., Greasley, P.J. and Wilstermann, M. (2007) Scaffold Hopping, Synthesis and Structure-Activity Relationships of 5,6-Diaryl-Pyrazine-2-Amide Derivatives: A Novel Series of CB1 Receptor Antagonists. Bioorganic Medicinal Chemistry Letters, 15, 4077-4084. http://dx.doi.org/10.1016/j.bmc.2007.03.075

[7] Adediran, S.A., Cabaret, D., Flavell, R.R., Sammons, J.A., Wakselman, M. and Pratt, R.F. (2006) Synthesis and $\beta$ Lactamase Reactivity of $\alpha$-Substituted Phenaceturates. Bioorganic Medicinal Chemistry Letters, 14, 7023-7033. http://dx.doi.org/10.1016/j.bmc.2006.06.023

[8] Huang, Z., Hwang, P. Watson, D.S., Cao, L. and Szoka Jr., F.C. (2009) Tris-Nitrilotriacetic Acids of Subnanomolar Affinity toward Hexahistidine Tagged Molecules. Bioconjugate Chemistry, 20, 1667-1672. http://dx.doi.org/10.1021/bc900309n

[9] Zangl, A., Kluefers, P., Schaniel, D. and Woike, T. (2009) Photoinduced Linkage Isomerism of $\{\text { RuNO }\}^{6}$ Complexes with Bioligands and Related Chelators. Dalton Transactions, 1034-1045. http://dx.doi.org/10.1039/b812246f

[10] Luts, T., Suprun, W., Hofmann, D., Klepel, O. and Papp, H. (2007) Epoxidation of Olefins Catalyzed by Novel Mn(III) and Mo(IV) Salen Complexes Immobilized on Mesoporous Silica Gel. Journal of Molecular Catalysis A: Chemical, 261, 16-23. http://dx.doi.org/10.1016/j.molcata.2006.07.035

[11] Liu, Y., Pak, J.K., Schmutz, P., Bauwens, M., Mertens, J., Knight, H. and Alberto, R. (2006) Amino Acids Labeled with $\left[{ }^{99 \mathrm{~m}} \mathrm{Tc}(\mathrm{CO})_{3}\right]^{+}$and Recognized by the L-Type Amino Acid Transporter LAT1. Journal of the American Chemical Society, 128, 15996-15997. http://dx.doi.org/10.1021/ja066002m

[12] Takashima, H., Hirai, C. and Tsukahara, K. (2005) Selective and Monofunctional Guanosine 5'-Monophosphate Binding by Chloro[3-(2,3-diaminopropionylamino)propionic Acid](Dimethyl Sulfoxide)platinum(II) Complex. Bulletin of the Chemical Society of Japan, 78, 1629-1634. http://dx.doi.org/10.1246/bcsj.78.1629

[13] Rattat, D., Eraets, K., Cleynhens, B., Knight, H., Fonge, H. and Verbruggen, A. (2004) Comparison of Tridentate Ligands in Competition Experiments for Their Ability to Form a $\left[{ }^{99 m} \mathrm{Tc}(\mathrm{CO})_{3}\right]$ Complex. Tetrahedron Letters, 45, 25312534. http://dx.doi.org/10.1016/j.tetlet.2004.02.006

[14] Moura, S. and Pinto, E. (2010) Synthesis of Cyclic Guanidine Intermediates of Anatoxin-a(s) in both Racemic and Enantiomerically Pure Forms. Synlett, 2010, 967-969. http://dx.doi.org/10.1055/s-0029-1219559

[15] Becerril, A., León-Romo, J.L., Aviña, J., Castellanos, E. and Juaristi, E. (2002) Diastereoselective Alkylation of a Chiral 1,4-benzodiazepine-2,5-dione Containing the $\alpha$-Phenethyl Group. Attempted Asymmetric Synthesis of $\alpha, \beta$-diaminopropionic Acid. ARKIVOC, 2002, 4-14. http://dx.doi.org/10.3998/ark.5550190.0003.c02

[16] Brown, E.G. and Turan, Y. (1995) Pyrimidine Metabolism and Secondary Product Formation; Biogenesis of Albizziine, 4-Hydroxyhomoarginine and 2,3-Diaminopropanoic Acid. Phytochemistry, 40, 763-771. http://dx.doi.org/10.1016/0031-9422(95)00317-Z

[17] Fouques, D. and Landry, J. (1991) Study of the Conversion of Asparagine and Glutamine of Proteins into Diaminopro- 
pionic and Diaminobutyric Acids Using [Bis(trifluoroacetoxy)iodo]benzene Prior to Amino Acid Determination. Analyst, 116, 529-531. http://dx.doi.org/10.1039/an9911600529

[18] Hellmann, H. and Haas, G. (1957) Acylaminomethylation of CH-Acidic Compounds; Syntheses of $\beta$-Aminocarboxylic Acids. Chemische Berichte, 90, 1357-1363. http://dx.doi.org/10.1002/cber.19570900733

[19] Hellmann, H. (1957) Neuere Methoden der präparativen organischen Chemie II. 8. Amidomethylierungen. Angewandte Chemie, 69, 463-471. http://dx.doi.org/10.1002/ange.19570691305

[20] Oe, Y., Inoue, T., Kishimoto, H., Sasaki, M., Ohta, T. and Furukawa, I. (2012) Three-Component Coupling Catalyzed by Phosphine: Preparation of $\alpha$-amino $\gamma$-Oxo Acid Derivatives. International Journal of Organic Chemistry, 2, 111116.

[21] Riddick, J.A. and Bunger, W.B. (1970) Organic Solvent. 3rd ed., Wiley-Interscience, New York.

[22] Ross, J., Chen, W., Xu, L. and Xiao, J. (2001) Ligand Effects in Palladium-Catalyzed Allylic Alkylation in Ionic Liquids. Organometallics, 20, 138-142. http://dx.doi.org/10.1021/om000712y

[23] Nair, V., Sreekanth, A.R. and Vinod, A.U. (2001) Novel Pyridine-Catalyzed Reaction of Dimethyl Acetylenedicarboxylate with Aldehydes: Formal [2+2] Cycloaddition Leading to 2-Oxo-3-benzylidinesuccinates. Organic Letters, 3, 3495-3497. http://dx.doi.org/10.1021/ol016550z

[24] Trost, B.M. and Dake, G.R. (1997) Nitrogen Pronucleophiles in the Phosphine-Catalyzed $\gamma$-Addition Reaction. The Journal of Organic Chemistry, 62, 5670-5671. http://dx.doi.org/10.1021/jo970848e

[25] Rychnovsky, S.D. and Kim, J. (1994) Triphenylphosphine-Catalyzed Isomerizations of Enynes to (E,E,E)-Trienes: Phenol as a Cocatalyst. The Journal of Organic Chemistry, 59, 2659-2660. http://dx.doi.org/10.1021/jo00088a067

[26] Xu, Z. and Lu, X. (1999) Phosphine-Catalyzed [3+2] Cycloaddition Reactions of Substituted 2-Alkynoates or 2,3-alkenoates with Electron-Deficient Olefins and Imines. Tetrahedron Letters, 40, 549-552. http://dx.doi.org/10.1016/S0040-4039(98)02405-8

[27] Zhang, C. and Lu, X. (1995) Phosphine-Catalyzed Cycloaddition of 2,3-Butadienoates or 2-Butynoates with ElectronDeficient Olefins. A Novel [3+2] Annulation Approach to Cyclopentenes. The Journal of Organic Chemistry, 60, 2906-2908. http://dx.doi.org/10.1021/jo00114a048

[28] Xu, Z. and Lu, X. (1997) Phosphine-Catalyzed [3+2] Cycloaddition Reaction of Methyl 2,3-Butadienoate and N-Tosylimines. A Novel Approach to Nitrogen Heterocycles. Tetrahedron Letters, 38, 3461-3464. http://dx.doi.org/10.1016/S0040-4039(97)00656-4

[29] Guo, C. and Lu, X. (1993) Reinvestigation on the Catalytic Isomerization of Carbon-Carbon Triple Bonds. Journal of the Chemical Society, Perkin Transactions, 1993, 1921-1923. http://dx.doi.org/10.1039/p19930001921

[30] Trost, B.M. and Li, C.J. (1994) Phosphine-Catalyzed Isomerization-Addition of Oxygen Nucleophiles to 2-Alkynoates. Journal of the American Chemical Society, 116, 10819-10820. http://dx.doi.org/10.1021/ja00102a071

[31] Trost, B.M. and Kazmaier, U. (1992) Internal Redox Catalyzed by Triphenylphosphine. Journal of the American Chemical Society, 114, 7933-7935. http://dx.doi.org/10.1021/ja00046a062

[32] Trost, B.M. and Dake, G.R. (1997) Nucleophilic $\alpha$-Addition to Alkynoates. A Synthesis of Dehydroamino Acids. Journal of the American Chemical Society, 119, 7595-7596. http://dx.doi.org/10.1021/ja971238z

[33] Trost, B.M. and Li, C.J. (1994) Novel “Umpolung” in C-C Bond Formation Catalyzed by Triphenylphosphine. Journal of the American Chemical Society, 116, 3167-3168. http://dx.doi.org/10.1021/ja00086a074

[34] Kuroda, H., Hanaki, E. and Kawakami, M. (1999) A Convenient Method for the Preparation of Furans by the Phosphine-Initiated Reactions of Enynes Bearing a Carbonyl Group. Tetrahedron Letters, 40, 3753-3756. http://dx.doi.org/10.1016/S0040-4039(99)00601-2

[35] Nozaki, K., Sato, N., Ikeda, K. annd Takaya, H. (1996) Synthesis of Highly Functionalized $\gamma$-Butyrolactones from Activated Carbonyl Compounds and Dimethyl Acetylenedicarboxylate. The Journal of Organic Chemistry, 61, 45164519. http://dx.doi.org/10.1021/jo951828k

[36] Yavari, I. and Mosslemin, M.H. (1998) An Efficient One-Pot Synthesis of Dialkyl 2,5-dihydrofuran-2,3-dicarboxylates Mediated by Vinyltriphenylphosphonium Salt. Tetrahedron, 54, 9169-9174. http://dx.doi.org/10.1016/S0040-4020(98)00554-7

[37] Yavari, I., Hekmat-Shoar, R. and Zonouzi, A. (1998) A New Efficient Rout to 4-Carboxymethylcoumarins Mediated by Vinyltriphenylphosphonium Salt. Tetrahedron Letters, 39, 2391-2392.

[38] Yavari, I. and Baharfar, R. (1997) Vinylphosphonium Salt Mediated One-Pot Synthesis of Functionalized-3-(triphenylphosphoranylidene)butyrolactones. Tetrahedron Letters, 38, 4259-4262.

[39] Caddick, S., Aboutayab, K., Jenkins, K. and West, R.I. (1996) Intramolecular Radical Substitution Reactions: A Novel Approach to Fused [1,2-a] Indoles. Journal of the Chemical Society, Perkin Transactions, 1996, 675-682. http://dx.doi.org/10.1039/p19960000675

[40] Perrin, D.D. and Armarego, W.L.F. (1988) Purification of Laboratory Chemicals. 3rd Edition, Pergamon, Oxford. 
Scientific Research Publishing (SCIRP) is one of the largest Open Access journal publishers. It is currently publishing more than 200 open access, online, peer-reviewed journals covering a wide range of academic disciplines. SCIRP serves the worldwide academic communities and contributes to the progress and application of science with its publication.

Other selected journals from SCIRP are listed as below. Submit your manuscript to us via either submit@scirp.org or Online Submission Portal.
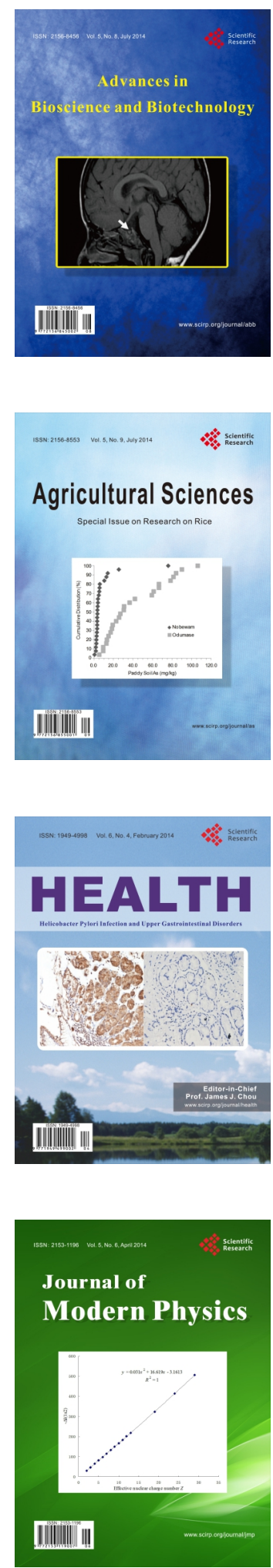
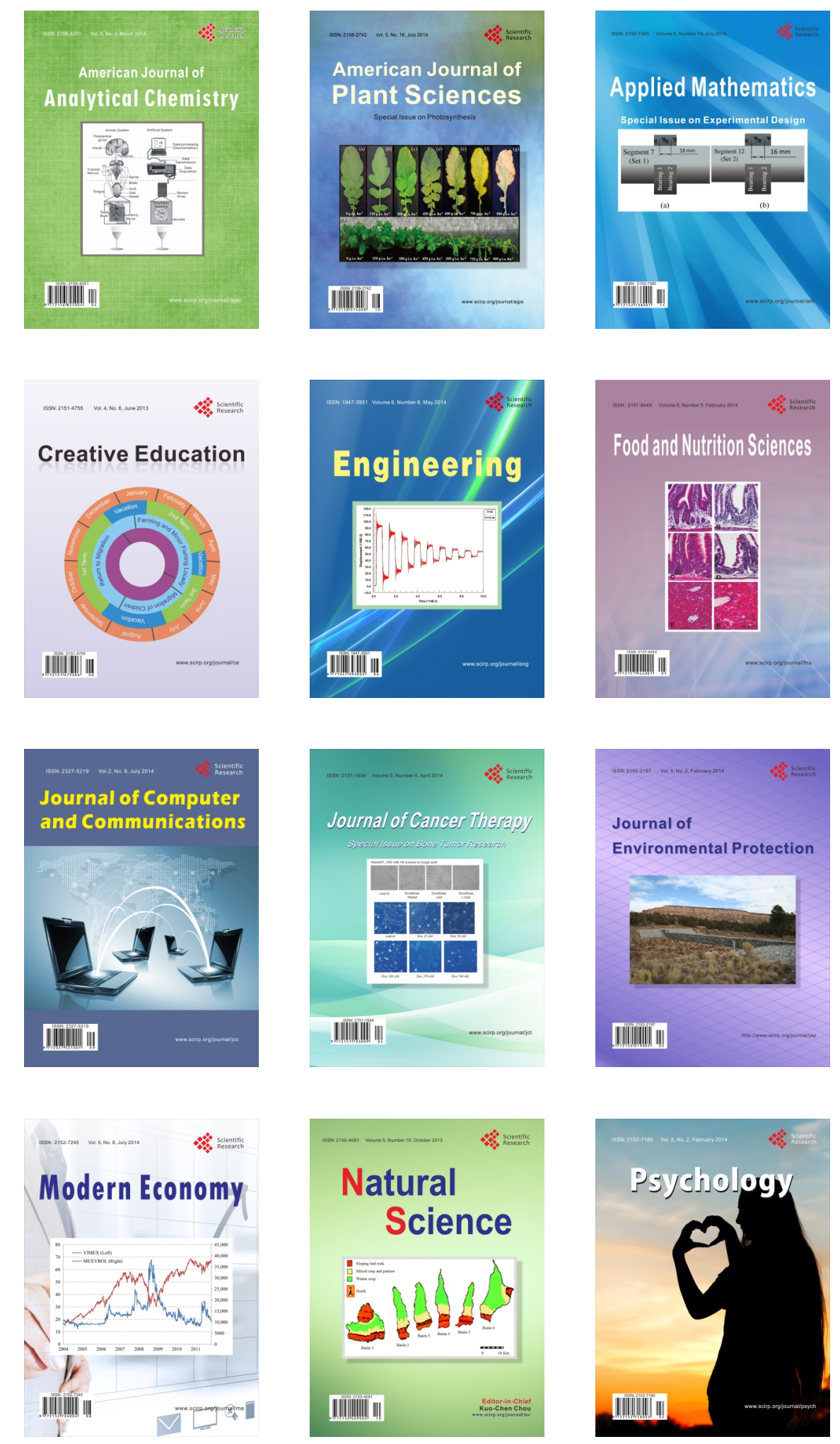